\title{
STRATEGI MANAJEMEN PRODUKSI FILM TELEVISI STARVISION TERHADAP ANGGARAN BIAYA PRODUKSI TERKAIT BUDAYA INDONESIA
}

\author{
Yessy Arisanti Wienata \\ Pascasarjana Institut Seni Indonesia Surakarta Pengkajian dan Penciptaan Seni \\ Jl. Ki Hadjar Dewantara 19, Surakarta 57126 Jawa Tengah \\ yessyawienata@gmail.com \\ Citra Ratna Amelia \\ Program Studi S-1 Televisi dan Film, \\ Fakultas Seni Rupa dan Desain Institut Seni Indonesia Surakarta \\ Jl. Ringroad Km 5.5 Mojosongo Surakarta 57127 Jawa Tengah
}

\begin{abstract}
Production management strategiesFTV Starvision related to Indonesian culture are the object of problems in research. The purpose of this study is to provide an understanding that the FTV Starvision shows are highly related to Indonesian culture. The results of the study concluded that Starvision in production FTV used several strategies at each stage of its production. Start from the stage preproduction, production, post production and evaluation. The strategy includes using newcomer performers whose salaries are still low, using locations that are often used so that in terms of licensing it is easier, to use vendors for equipment, and others. These strategies to save production costs. Another strategy is to use location, dialogue, accent, costume, property, which is very thick with Indonesian culture, it to introduce Indonesian culture through television media especially FTV.
\end{abstract}

Key Words : Management Strategy, Film Production Stage, Film Television (FTV) Starvision, Production Cost Budget, Indonesian Culture.

\begin{abstract}
Abstrak
Strategi manajemen produksi FTV Starvision yang berkaitan dengan budaya Indonesia menjadi objek masalah dalam penelitian. Tujuan dari penelitian ini untuk memberikan pemahaman bahwa tayangan FTV Starvision sangat terkait dengan budaya Indonesia. Hasil dari penelitian menyimpulkan bahwa Starvision dalam memproduksi FTV menggunakan beberapa strategi dalam setiap tahapan produksinya. Mulai dari tahapan praproduksi, produksi, pascaproduksi dan evaluasi. Strategi tersebut antara lain, menggunakan pemain artis pendatang baru yang honornya masih rendah, penggunaan lokasi yang sering digunakan agar segi perizinan dipermudah, penggunaan vendor untuk peralatan, dan lain-lain. Strategi-strategi tersebut bertujuan untuk penghematan biaya produksi. Strategi lain yakni menggunakan lokasi, dialog, logat, kostum, properti yang sangat kental dengan Budaya Indonesia, hal tersebut bertujuan agar dapat mengenalkan budaya Indonesia melalui media televisi khususnya tayangan FTV.

Kata Kunci : Strategi Manajemen, Tahapan Produksi Film, Film Televisi (FTV) Starvision, Anggaran Biaya Produksi, Budaya Indonesia.
\end{abstract}




\section{PENDAHULUAN}

Film televisi atau lebih dikenal dengan istilah FTV adalah jenis film fiksi yang diproduksi dengan durasi penayangan 120 menit. Film televisi mulai banyak diproduksi di Indonesia pada awal tahun 1995 yang dipelopori oleh SCTV, hal ini dilakukan untuk menjawab kejenuhan penonton atas sinetron di Indonesia. Starvision sendiri memiliki tiga bidang usaha meliputi film layar lebar, TV program dan FTV. Pengelolaan produksi FTV di Starvision adalah sudah adanya template atau beberapa tim khusus untuk produksi FTV.

Starvision memiliki delapan sutradara yang memproduksi FTV. Tujuh sutradara di Starvision selain memproduksi FTV, juga memproduksi sinetron secara stripping ataupun film layar lebar. Sedangkan satu sutradara yang sampai saat ini konsisten hanya memproduksi FTV adalah sutradara Lakonde. Starvision harus memproduksi kurang lebih delapan FTV dalam satu bulannya, karena Starvision memiliki tanggung jawab untuk memberikan tayangan FTV kepada SCTV untuk ditayangkan pada hari Rabu dan Sabtu pada pukul 10.00 WIB dengan durasi 120 menit setiap judulnya. Jumlah FTV yang disetorkan ke pihak SCTV harus terpenuhi, sehingga Starvison harus memproduksi FTV secara maraton.

Waktu untuk memproduksi satu judul FTV dimulai dari tahap praproduksi hingga pascaproduksi adalah kurang lebih tujuh belas hari. Waktu tersebut terbagi dalam enam hari untuk tahap praproduksi, lima hari untuk tahap produksi, dan enam hari sisanya untuk tahap pascaproduksi. Pada tahap praproduksi waktu dibagi kembali yakni tiga hari untuk proses perencanaan dan pengorganisasian serta tiga hari sisanya untuk proses diskusi internal. Tahap produksi yang berlangsung selama lima hari digunakan untuk proses syuting secara menyeluruh. Setelah syuting selesai dilakukan, maka masuk ke tahap pascaproduksi. Pada tahapan ini hasil syuting kemudian diedit, sementara prosesnya berlangsung, pihak Starvision menggunakan waktu tersebut untuk memproduksi judul FTV lainnya. Hal tersebut diterapkan kepada delapan sutradara di Starvision. Setiap sutradara di Starvision sudah memiliki tim produksi dan peralatan produksi sendiri-sendiri. Oleh karena itu setiap sutradara dapat memproduksi FTV minimal dua judul dalam satu bulannya. Sehingga jumlah target delapan judul yang harus dikirimkan ke pihak SCTV selalu dapat terpenuhi.

Terkait dengan budaya Indonesia, banyak sekali kebudayaan yang ada di Indonesia. Budaya adalah suatu cara hidup yang berkembang dan dimiliki bersama oleh sebuah kelompok orang dan diwariskan dari genenrasi ke generasi. Budaya merupakan gabungan dari unsur rumit, seperti sistem agama, politik, adat istiadat, bahasa, peralatan, pakaian, bangunan, dan karya seni. Perbedaan antara budaya dan kebudayaan adalah bahwa budaya merupakan cipta, rasa, dan karsa suatu masyarakat sedangkan kebudayaan merupakan hasil dari ketiga tersebut. Tetapi walaupun demikian budaya dan kebudayaan merupakan suatu kesatuan yang utuh dan tidak dapat dipisahkan satu sama lain. Budaya dan kebudayaan saling terkait dan bersinggungan. Demikian pula dalam tayangan FTV, mulai dari pencarian ide hingga proses edit FTV, budaya tersebut sangat dekat dengannya. Penentuan ide, penulisan skenario, penentuan judul, pemilihan lokasi dan pemain pun sangat terkait dengan budaya Indonesia. Bahasa dan logat pun menyesuaikan dengan budaya apa yang akan diangkat atau dijadikan ide dalam pembuatan FTV. 
Waktu untuk memproduksi setiap judul FTV dengan durasi 120 menit yang hanya berlangsung selama tujuh belas hari dirasa sangat efisien. Biaya produksi perjudul FTV adalah Rp. 250.000.000 sampai Rp. 275.000.000. Sistem penjualan FTV dari Starvision kepada SCTV adalah dengan sistem penjualan jual putus. Sehingga penayangan FTV yang ditayangkan kembali oleh SCTV tidak memberikan keuntungan lagi bagi Starvision. Produksi FTV ini yang utama adalah kuantitas, meskipun tetap menjaga kualitas tayangan. Terkait dengan budaya Indonesia, pembuatan FTV sangat terkait dengan budaya Indonesia. Proses praproduksi hingga pascaproduksi pun sangat terkait dengan budaya Indonesia. Dengan efektifnya waktu produksi, secara otomatis pengeluaran biaya produksi juga akan efisien. Untuk dapat menggunakan anggaran secara efektif dan efisien tentu saja tidak lepas dari strategi manajemen produksi di Starvision. Hal tersebut tentu saja menjadi sesuatu yang menarik untuk diteliti tentang bagaimana strategi manajemen produksi FTV di Starvision terkait budaya Indonesia yang digunakan untuk mengontrol penggunaan anggaran biaya produksi.

\section{METODE PENELITIAN}

Metode yang dilakukan dalam penelitian ini adalah dengan metode penelitian kualitatif. Penelitian kualitatif adalah prosedur penelitian yang menghasilkan data deskriptif. Menurut Moloeng dalam bukunya Metode Penelitian Kualitatif, penelitian kualitatif adalah penelitian yang bermaksud untuk memahami fenomena tentang apa yang dialami oleh subjek penelitian. Sumber data utama dalam penelitian kualitatif adalah kata-kata dan tindakan, selebihnya berupa data tambahan seperti dokumen, tayangan dan lain-lain. Sumber data primer dalam penelitian ini berupa kata-kata diperoleh dari wawancara dengan tiga informan yang telah ditentukan meliputi berbagai hal yang berkaitan dengan strategi manajemen produksi FTV di Starvision terhadap anggaran biaya produksi. Penelitian dikuatkan dengan didapatkannya sumber data sekunder berupa company profile Starvision dan tayangan FTV di SCTV. Penayangan FTV juga dapat dilihat secara offline di vidio.com, youtube dan untuk mendapatkan triller dan poster dari FTV yang akan tayang atau yang telah tayang bisa dilihat di akun instagram starvision.ftv.

Teknik pengumpulan data adalah cara-cara yang dapat digunakan oleh peneliti untuk mengumpulkan data dengan lengkap. Teknik pengumpulan data untuk penelitian ini yaitu menggunakan beberapa teknik yang berbeda yaitu dengan observasi, wawancara dan studi pustaka. Observasi ini menggunakan observasi partisipasi, dimana seorang observer terlibat langsung dengan kegiatan seharihari orang yang sedang diamati atau yang digunakan sebagai sumber data penelitian. Observasi partisipatif dilakukan secara langsung untuk mengamati dan terlibat langsung dalam proses produksi FTV pada bulan Oktober hingga Desember 2017. Wawancara dilakukan untuk mendapatkan jawaban dari tiga informan yang telah ditentukan meliputi berbagai hal yang berkaitan dengan strategi manajemen produksi FTV di Starvision terhadap anggaran biaya produksi. Wawancara dilakukan dengan dua cara yakni wawancara secara langsung (bertatap muka) dan wawancara tidak langsung (melalui via Whatsapp). Wawancara dilakukan dengan manajer produksi FTV di Starvision yakni Nur Samsi, sutradara Lakonde dan penulis skenario Endik Koeswoyo. Untuk melengkapi data, maka diperlukan studi dokumen dengan cara 
mencari data yang berkaitan dengan budaya Indonesia dan melihat tayangan langsung di stasiun televisi SCTV ataupun di akun vidio.vom.

\section{HASIL DAN PEMBAHASAN}

Starvision adalah rumah produksi yang memiliki beberapa bidang usaha meliputi, pembuatan film layar lebar, sinetron, dan FTV. Keberadaan Starvision pada industri perfilman Indonesia memiliki andil yang cukup besar. Salah satu misi yang diusung oleh Starvision yaitu menciptakan beragam program yang kreatif inovatif dan berkualitas. Starvision ingin selalu ada tuntunan dalam karyanya agar menjadi trendcenter dan menghibur dimata masyarakat. Website perusahaan Starvision adalah www.klikstarvision.com.

Tim produksi FTV di Starvision bersifat freelance, sehingga individuindividu yang termasuk tim produksi dapat berganti sesuai dengan kebutuhan produksi. Tim produksi Starvision bekerja secara profesional, yaitu bekerja sesuai dengan job desc masing masing. Tim produksi Starvision sudah memiliki pola sendiri untuk melakukan proses produksi. Sehingga Starvision tidak harus mengeluarkan biaya lebih untuk mempekerjakan individu yang tidak profesional, karena Starvision akan mengalami kerugian jika individu tersebut tidak dapat bekerja sesuai dengan pola yang dilakukan oleh tim produksi Starvision. Starvision memiliki delapan sutradara, sehingga kerabat kerja (kru) nya pun juga terdiri dari delapan kelompok. Nama dari tim produksi akan ditampilkan dalam credit title tayangan FTV Starvision.

Strategi manajemen adalah serangkaian dari pada keputusan manajerial dan kegiatan-kegiatan yang menentukan keberhasilan perusahaan dalam jangka panjang. Kegiatan tersebut terdiri dari perumusan atau perencanaan strategi, pelaksanaan dan evaluasi. Strategi manajemen produksi merupakan sebuah rencana yang didesain sedemikian rupa untuk mencapai sasaran tertentu. Starvision merupakan rumah produksi yang memproduksi FTV dalam seminggu sebanyak dua episode, sehingga dalam satu bulan Starvision harus memproduksi FTV sebanyak lebih dari delapan episode.

Budaya Indonesia, terkait dengan budaya Indonesia, FTV sangat dekat dengan budaya Indonesia. Pemilihan lokasi untuk proses syuting, pemilihan pemain dengan logat dan bahasa yang sesuai dengan cerita, properti yang dibutuhkan, kostum yang digunakan, kesenian apa yang akan diangkat pada tayangan FTV Starvision, semua itu mencerminkan bahwa tayangan FTV Starvision sangat dekat dengan budaya Indonesia. Sehingga budaya Indonesia dapat dipopulerkan atau dipromosikan melalui tayangan FTV SCTV dan nyatanya, FTV sangat terkait dengan budaya Indonesia.

FTV yang diproduksi oleh Starvision ditayangkan di SCTV pada hari Rabu dan Sabtu pada pukul 10.00 WIB. Starvision bukan satu-satunya rumah produksi yang memproduksi tayangan FTV, melainkan ada beberapa rumah produksi lain yang juga memproduksi tayangan FTV. Produksi FTV di Starvision yang diutamakan adalah kuantitas, meskipun juga tetap menjaga kualitas tayangan FTV. Oleh sebab itu Starvision harus menerapkan strategi manajemen produksi FTV untuk tetap bertahan dalam menghadapi persaingan industri dengan rumah produksi lain dan tetap produktif, terhadap anggaran biaya produksi yang digunakan. Starvision dalam memproduksi FTV menggunakan beberapa strategi dalam setiap tahapan produksinya. Mulai dari 
tahapan praproduksi, produksi, pascaproduksi dan evaluasi.

\section{Praproduksi}

Proses praproduksi Starvision berlangsung selama enam hari. Hal tersebut dibagi dalam dua proses yakni tiga hari untuk proses perencanaan dan pengorganisasian serta tiga hari untuk proses diskusi internal. Menurut peneliti, tahapan praproduksi di Starvision yang berlangsung selama enam hari tersebut dirasa sangat singkat, karena untuk mempersiapkan segala kebutuhan produksi membutuhkan waktu yang cukup lama. Tetapi jika dilihat dari jumlah episode FTV yang wajib ditayangkan setiap bulan, maka penggunaan lama waktu yang singkat tersebut dirasa sangat efektif untuk menekan biaya produksi. Jika lama waktu pada tahapan praproduksi semakin lama, maka anggaran biayanya pun juga akan bertambah. Jadi penggunaan waktu yang singkat pada tahapan praproduksi merupakan strategi Starvision yang cukup efektif dan efisien untuk menekan biaya produksi. Tahapan praproduksi penting dilakukan untuk merencanakan segala sesuatu yang akan menentukan keberhasilan tayangan FTV yang diproduksi oleh Starvision.

Tahapan ini tidak lepas dari kerjasama tiga pihak yang disebut triangle system. Triangle system adalah kerja sama antara tiga pihak yaitu produser, sutradara dan penulis naskah untuk penggarapan sebuah karya film. Produksi FTV di Starvision dimulai dengan proses pencarian ide (gagasan) yang telah dituliskan dalam sebuah sinopsis. Pada proses pencarian sinopsis, Starvision mencari sinopsis dari hasil karya para penulis sinopsis lepas yang dikirimkan ke email Starvision. Sinopsis-sinopsis yang telah masuk kemudian dipilah dan dipilih oleh sekretaris produser Starvision. strategi yang digunakan Starvision dalam pemilihan sinopsis awal adalah dengan melihat track record dari penulis sinopsis yang sudah sering mengirimkan sinopsisnya ke pihak Starvision. Jika Starvision membuka peluang bagi penulis dari luar untuk mengirimkan sinopsis mereka, maka Starvision akan banyak pekerjaan untuk menseleksi sinopsis yang telah terkirim tersebut. Untuk strategi anggaran biaya produksi, pemilihan sinopsis dengan melihat track record di rasa sangat efektif karena Starvision dapat membuat anggaran biaya produksi yang pasti. Dengan melihat track record, Starvision sudah mengerti berapa harga untuk satu sinopsis dari penulis Starvision. Hal tersebut merupakan sebuah strategi yang dirasa cukup efektif dan efisien dalam hal waktu, tenaga dan biaya produksi.

FTV Starvision memiliki genre tetap yaitu drama, romantik dan komedi, dan tema yang digunakan pada produksi FTV di Starvision dikelompokkan menjadi tema profesi, adventure, fiksi, adaptasi film, dan lainlain. Strategi tema yang sering dipakai Starvision adalah tema profesi. Tema profesi yang sering digunakan Starvision adalah tema profesi yang bersifat bergerak. Tema profesi yang bersifat bergerak adalah suatu pekerjaan yang menuntut pekerjaannya berkeliling untuk menjajakan barang dagangannya. Terkait dengan tema yang akan diproduksi, Starvision melihat apa yang saat ini trending dan terkait dengan budaya Indonesia, misal ondelondel merupakan kesenian betawi, dangdut merupakan genre musik warisan budaya Indonesia, dan masih banyak tema-tema lainnya yang terkait dengan budaya Indonesia.

Menurut peneliti, penggunaan tema profesi bertujuan agar proses produksi FTV di Starvision akan lebih leluasa, dapat bertemu dengan banyak orang, dan mudah 
untuk membangun cerita. Starvision selalu memilih tema profesi karena setting lokasi yang digunakan akan selalu berada diluar ruangan (outdoor). Hal tersebut dapat menghemat biaya produksi karena penggunaan lampu dapat diminimalisir. Setelah sinopsis dipilah dan dipilih, sinopsis yang terpilih kemudian dikirimkan ke pihak SCTV. Setelah pihak SCTV memilih sinopsis, selanjutnya pihak SCTV akan mengirimkan balik sinopsis yang telah dipilih kepada pihak Starvision. Proses pembayaran sinopsis terjadi setelah sinopsis tersebut disetujui oleh pihak SCTV. Pembayaran dilakukan dengan cara ditransfer langsung oleh pihak Starvision kepada penulis yang sinopsisnya telah terpilih. Pembelian sinopsis dengan pembayaran diakhir merupakan strategi untuk menekan biaya produksi, karena jika pembayaran dilakukan diawal, maka pihak Starvision akan dirugikan.

\section{a. Perencanaan}

Proses perencanaan di Starvision mendefinisikan tujuan memproduksi FTV, membuat strategi dan memberi formula pada tayangan FTV dengan selalu meningkatkan kreativitas, agar dapat mencapai tujuan dari penayangan FTV dengan cara menekan biaya produksi. Sehingga hal tersebut dapat digunakan oleh Starvision untuk dapat bertahan dalam menghadapi persaingan industri. Proses perencanaan di Starvision dihadiri oleh produser, produser pelaksana, produser kreatif, manajer produksi, editor, sutradara beserta chip, casting directordan penulis naskah. Proses ini dilakukan dengan sistem TM (Technical Meeting).

\section{Pembuatan Skenario}

Dalam proses ini, sinopsis yang telah disetujui oleh pihak SCTV akan diubah menjadi sceneplot atau treatment. Setelah penulisan sceneplot selesai maka masuklah pada pembuatan skenario yang nantinya akan berfungsi sebagai tuntunan pada proses produksi.

Menurut peneliti dengan melihat buku karya Bastian Cleve yang berjudul Film Production Management tahun 2000 mengenai pembuatan skenario dengan biaya produksi rendah, dapat dijelaskan bahwa di dalam skenario harus menghindari penggunaan lokasi-lokasi asing, hindari melibatkan banyak pemain, minimalisir adegan action, lebih mementingkan dialog antar pemain dan pengembangan plot, diminimalisir penggunaan stuntman, spesial efek, penulis harus dapat menentukan berapa lama durasi yang dibutuhkan untuk merealisasikan scene-scene tersebut dan biaya yang harus dikeluarkan.

Hal tersebut juga digunakan oleh Starvision. Sebagai contoh skenario FTV Starvision yang berjudul Lady Bikers Idola Hati karya Ugih Sugianto. Mengenai lokasi, proses produksi FTV di Starvision menggunakan lokasi-lokasi yang sering digunakan dengan tujuan agar dalamsegi perijinan tidak mengalami kesulitan. Lokasi yang sering digunakan Starvision untuk produksi FTV yaitu lokasi dengan jarak yang dekat dan masih di sekitaran Jakarta.

Pada judul ini menggunakan lima lokasi. Lokasi-lokasi tersebut ialah TMII, Studio Persari, kos-kos an, sirkuit dan rumah kucing. Hal tersebut digunakan sebagai strategi penghematan biaya produksi, karena tidak perlu mengeluarkan biaya lebih untuk transportasi dan akomodasi. Pemain yang digunakan dalam judul FTV ini yaitu dua pemain utama, lima pemain pembantu utama, tujuh figuran dialog dan ada beberapa ekstras. Properti yang digunakan dalam judul ini yang paling penting ialah motor balap lengkap dengan helmnya. Pada judul FTV Lady Bikers Idola Hati lebih mementingkan 
dialog dan ekspresi pemain dibandingkan adegan action-nya, maka tidak perlu menggunakan stuntman.

Judul lain yang terkait budaya Indonesia, Backpaker Kece Tapi Kere dan I Love You Full Bu Dosen, menggunakan lokasi di luar Jakarta. Proses produksi FTV judul-judul tersebut menggunakan lokasi dimana budaya Indonesia masih sangat kental yaitu di daerah Istimewa Yogyakarta. Hal tersebut digunakan Starvision untuk mengurangi kejenuhan penonton agar lokasi yang digunakan syuting tidak di area Jakarta saja.

Penentuan Judul FTV

Skenario disusun oleh seorang penulis naskah. Penulis naskah di Starvision bersifat freelance. Penentuan judul skenario FTV di Starvision ditentukan oleh SCTV. Penggunaan judul dengan kata-kata tidak baku dirasa lebih mengena ke penonton FTV pada jam penayangan FTV, sehingga penggunaan judul tidak baku sangat efektif digunakan untuk menarik perhatian penonton tayangan FTV Starvision. Menurut peneliti, penggunaan kata-kata tidak baku pada penulisan judul FTV di Starvision dapat dijadikan sebagai strategi untuk menarik perhatian penonton, sehingga Starvision dapat menayangkan FTV secara kontiniti, agar profit yang diberikan oleh SCTV bisa menjadi biaya untuk produksi FTV judul selanjutnya.

Terkait dengan judul FTV, budaya Indonesia juga masuk kedalamnya, contoh judul FTV SCTV yang ada dan terkait budaya Indonesia adalah Dangdut Is The Musik Of My Darling, Mbok Jamu Milenial Cintanya Ambyar, Tukang Bajaj Undercover, Bule Norak jadi Ondel-Ondel dan masih banyak lagi.

\section{Pemilihan Pemain}

Proses pemilihan pemain utama untuk produksi FTV adalah dengan cara mencari dan memilih pemain yang saat ini sudah memiliki fans atau penggemar yang tinggi. Starvision dalam memilih pemain berpedoman pada kriteria yang telah ditentukan sebelumnya. Kriteria-kriteria tersebut meliputi pemain yang mendekati karakter dalam cerita, artis pendatang baru dan sudah memiliki penggemar yang banyak. Menggunakan pemain pendatang baru dengan memiliki penggemar banyak merupakan strategi Starvision yang sangat efektif untuk menghemat biaya produksi. Pemain dengan memiliki penggemar banyak secara spontan akan menarik perhatian penggemar tersebut untuk melihat tayangan FTV yang diperankan oleh idolanya. Hal tersebut juga dapat dijadikan sebagai strategi untuk promosi yang sangat efektif dan efisien. Sehingga hal tersebut menjadi strategi untuk menghemat biaya produksi FTV di Starvision.

Terkait dengan budaya Indonesia, pemilihan pemain juga merupakan penentu agar judul FTV ini mendapat rating tinggi, jika judul FTV mengangkat kebudayaan orang Jawa, pemainnya pun juga harus bisa berlogat ataupun berbahasa Jawa. Contoh judul FTV Cinta Manja Cleaning Service Cantik, dalam cerita FTV tersebut menjelaskan bahwa pemain cowonya berasal dari Jawa, sehingga mengharuskan ia dapat berbahasa jawa minimal berlogat Jawa. Hal tersebut sudah dapat mencerminkan bahwa FTV sangat terkait dengan budaya Indonesia.

\section{Persiapan Peralatan Produksi}

Peralatan yang digunakan untuk produksi FTV di Starvision berupa peralatan produksi lengkap seperti seperangkat kamera, lighting, audio dan seperangkat peralatan teknis lainnya sesuai 
kebutuhan produksi. Strategi yang digunakan Starvision mengenai peralatan produksi adalah mencari vendor yang mau meminjamkan alatnya (sewa) dengan tujuan untuk meringankan biaya produksi. Hasil analisis yang dilakukan peneliti menyimpulkan bahwa pencarian vendor untuk produksi FTV dapat menghemat biaya produksi. Sistem vendor di Starvision ialah bahwa pemberi vendor akan menyewakan peralatan produksi kemudian pemberi vendor tersebut akan dimasukkan kedalam credit title.

\section{Anggaran Biaya Produksi}

Anggaran biaya produksi sangat penting dilakukan untuk mengetahui banyak dan sedikitnya kebutuhan produksi. Anggaran atau budget yang dibutuhkan untuk produksi FTV di Starvision adalah Rp.250.000.000 - Rp.275.000.000 setiap satu judulnya. Strategi menghemat anggaran biaya produksi FTV Starvision adalah pemilihan pemain pendatang baru yang fee (honor) nya belum terlalu mahal (pemain utama Rp. 6.000.000 sampai Rp. 20.000.000 perjudul, pemain pembantu utama Rp. 2.000.000 sampai Rp. 6.000.000 perjudul, figuran Rp. 60.000 sampai $\mathrm{Rp}$. 300.000 perhari), pemilihan lokasi yang tidak jauh dan sering digunakan untuk meringankan biaya perjalanan dan sewa lokasi, peralatan yang digunakan merupakan peralatan yang dipinjami oleh vendor, sehingga Starvision tidak mengeluarkan biaya lebih untuk sewa dan perawatan alat.

\section{a. Pengorganisasian}

Pengorganisasian adalah menata sebagian elemen ke dalam sebuah urutan hubungan atau mengumpulkan sumber daya yang diperlukan untuk mencapai tujuan organisasi. Pengorganisasian dalam manajemen produksi adalah perekrutan atau penyusunan tim inti yang sesuai dengan kapabilitas sumber daya manusia dan bakat-bakat yang ada. Struktur organisasi di Starvision tidak hanya tim ini, tetapi juga ada tim kreatif. Tim kreatif di Starvision bersifat freelance. Tim kreatif dapat disebut sebagai tim produksi yang terdiri dari sutradara, asisten sutradara, script continuity, DOP, operator kamera, divisi art, divisi lighting, divisi sound, divisi makeup dan kostum, unit manajer, $\mathrm{PU}$, dan individu lainnya sesuai kebutuhan produksi.

Perekrutan kru dan tim inti dilakukan dengan sistematika perekrutan karyawan yaitu melalui lamaran kemudian melakukan interview lalu tes per divisi. Tim kreatif menerima pelajar atau mahasiswa untuk magang. Peserta magang akan diberi tugas sesuai dengan keahlian pelajar atau mahasiswa magang tersebut. Mahasiswa atau pelajar magang ditempatkan dalam pekerjaan yang sama dengan kru produksi. Hal tersebut merupakan strategi Starvision dalam memproduksi FTV untuk menghemat biaya produksi, karena Starvision tidak perlu mengeluarkan uang untuk memberi honor kepada peserta magang.

\section{b. Diskusi Internal}

Diskusi internal yaitu proses bertukar pikiran antara sutradara beserta tim kreatif untuk membahas kelanjutan skenario yang didapat dari tahapan sebelumnya kemudian mengunci skenario (lock skenario) tersebut untuk di breakdown. Menurut observasi yang dilakukan peneliti, pada proses diskusi internal dengan lama waktu tiga hari tersebut sudah dapat melakukan proses breakdown naskah, breakdown pemain, hunting lokasi, menyiapkan kostum, properti, makeup, peralatan produksi, dan kru. Dalam proses ini kru yang dilibatkan adalah chip dari per divisi tim kreatif dan diketuai oleh seorang sutradara. Sutradara sebagai pemimpin diskusi merupakan strategi yang dilakukan Starvision dengan 
tujuan agar mendapatkan sasaran yang sama (satu pikiran). Selain itu juga dapat mempermudah pekerjaan serta lebih efisien waktu dan tenaga.

\section{Lock Skenario}

Lock skenario merupakan proses yang dilakukan sutradara untuk membuat logis beberapa scene yang dirasa kurang logis. Proses ini dilakukan dengan cara berdiskusi antara sutradara beserta tim untuk menghapus atau menambah scene agar terlihat logis. Kru yang terlibat dalam proses ini ialah sutradara beserta ketua (chip) per divisi tim kreatif. Menurut peneliti, seharusnya skenario sudah harus dimatangkan pada proses perencanaan, sehingga tidak lagi diperlukan proses lock skenario. Hal tersebut menjadi strategi agar dapat menghemat waktu praproduksi.

\section{Pemanggilan Kru Produksi}

Kru produksi adalah sekumpulan individu dengan keahlian masingmasing sesuai kebutuhan teknis produksi FTV. Kru produksi terdiri dari sutradara, asisten sutradara atau astrada schedule, astrada set, script continuity, DOP, divisi art, wardrobe,lighting, sound, unit dan unit lokasi, PU dan penanggung jawab alat. Strategi yang digunakan Starvision dalam proses ini adalah selalu menjaga komunikasi antara tim inti dengan tim kreatif, karena dalam proses pembuatan FTV harus melibatkan banyak orang. Komunikasi yang baik menjadi salah satu strategi yang digunakan Starvision untuk menghadapi persaingan industri penayangan FTV yang semakin berkembang.

\section{Breakdown Naskah}

Dapat dimengerti bahwa arti dari breakdown naskah adalah uraian naskah skenario menjadi bagian-bagian yang menggambarkan tiap detil adegan untuk membantu proses pengambilan gambar. Asisten sutradara schedule beserta sutradara bertugas untuk menyusun breakdown naskah. Strategi yang digunakan dalam tahapan ini adalah dengan memberikan sceneplot kepada astrada schedule untuk segera dibreakdown. Kemudian dilanjutkan dengan membuat breakdown secara keseluruhan dari proses lock skenario. Setelah breakdown selesai disusun, astrada schedule akan membagikan kepada ketua tiap divisi untuk dibreakdown sesuai dengan kebutuhan masing-masing divisi tersebut. Hal ini termasuk strategi yang digunakan Starvision untuk menghemat waktu produksi.

\section{Hunting Lokasi}

Hunting lokasi adalah proses mencari lokasi (tempat) sesuai dengan tuntutan skenario film. Hunting lokasi dilakukan oleh asisten sutradara dan unit produksi dengan persetujuan sutradara dan manajer produksi. Hunting lokasi dilakukan setelah proses breakdown naskah selesai. Lokasi yang sering digunakan Starvision untuk produksi FTV adalah Studio Persari. Studio Persari adalah sebuah area luas yang didalamnya terdapat banyak setting bangunan dan taman. Persari Film merupakan sebuah studio rumah produksi perfilman dari Indonesia. Perusahaan ini merupakan perusahaan film tertua yang didirikan oleh Djamaludin Malik dan masih bertahan sampai saat ini. Studio Persari sangat sering digunakan sebagai lokasi produksi FTV Starvision karena memiliki luas 33.000 meter persegi, sehingga di dalam Studio Persari terdapat banyak set, seperti rumah sakit, kantor, kantin, taman, rumah dan lain-lain.

Gambar 01. Denah Studio Persari

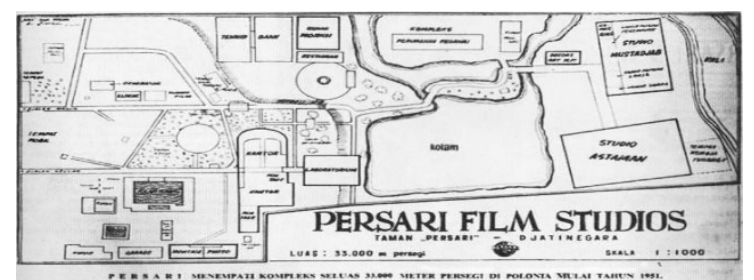

(Sumber:www.commons.wikipedia.org.2018) 
Faktor penting dalam produksi untuk menekan biaya adalah dengan penggunakan lokasi yang sedikit mungkin, dapat di jangkau, penggunaan lokasi lokal, serta mencari lokasi yang dapat digunakan untuk beberapa set sehingga tidak bongkar pasang. Penggunan lokasi lokal mempunyai banyak kelebihan, ialah tidak membutuhkan transportasi dan biaya penginapan. Hal tersebut digunakan sebagai strategi untuk mengurangi biaya sewa dan perizinan terlebih juga dapat menghemat waktu.

\section{Mencari Pemain Pendukung}

Pemain pendukung adalah seseorang yang mendukung atau membantu pemain utama dalam proses produksi FTV. Seseorang yang memiliki tugas mencari pemain pendukung adalah astrada beserta casting director dengan persetujuan sutradara. Pemilihan pemain pendukung berdasarkan usulan dari tim kreatif merupakan strategi yang digunakan Starvision untuk menghemat biaya produksi, efisien waktu dan tenaga, karena sudah tidak lagi memerlukan proses casting yang hanya memperpanjang waktu dan menambah biaya produksi, sehingga tidak lagi memberikan pengarahan mengenai bagaimana ia harus berperan. Pemain pendukung harus sudah bisa acting tanpa harus di beritahu terlebih dahulu.

\section{Produksi}

Tahap produksi adalah seluruh kegiatan pengambilan gambar (shooting) baik di dalam ruangan maupun di luar ruangan. Tahap produksi Starvision hanya berlangsung selama lima hari. Proses produksi membutuhkan semua kru produksi bekerja sesuai dengan divisinya masing masing secara profesional. Profesional dalam artian bekerja sesuai dengan job decs masingmasing. Sehingga hal tersebut menjadi strategi yang bertujuan untuk menghemat waktu dan tenaga. Produksi diawali dengan berdoa bersama kru dan pemain, mempersiapkan kebutuhan produksi seperti penempatan lighting, kamera dan sound serta penempatan properti. Setelah berdoa, produksi dapat dilakukan setelah astrada schedule memberi perintah kepada semua tim untuk scene berapa yang akan diambil terlebih dahulu gambarnya. Ini menjadi strategi tim kreatif untuk menyatukan rasa dan solidaritas di lokasi produksi. Starvision tidak menggunakan proses reading pada tahapan produksi, tetapi diganti dengan direct sutradara langsung di set lokasi.

Menurut peneliti, proses produksi di Starvision sangatlah singkat yaitu lima hari produksi. Proses tersebut dilakukan dengan cara profesional untuk menghasilkan tayangan yang berkualitas dengan durasu 120 menit. Bisa disebut proses produksi FTV di Starvision adalah proses produksi yang serba instan yang tidak memerlukan proses reading pemain sebelum shooting. Hal tersebut dilakukan karena untuk menyingkat waktu dan menghemat biaya produksi sehingga penggunaan direct sutradara secara langsung di lapangan merupakan strategi yang cukup efektif untuk menghemat biaya produksi.

\section{a. Reading Pemain}

Reading pemain adalah proses yang dilakukan oleh pemain dengan dibantu oleh script continuity untuk membaca naskah atau skenario. Reading pemain dilakukan sebelum proses pengambilan gambar sembari pemain melakukan makeup. Reading pemain dilakukan oleh script continuity di backstage (bagian makeup, wardrobe dan kostum). Reading pemain dilakukan dengan cara script continuity membacakan dialog scene berapa yang mau di take, lalu pemain akan menjawab dialog yang menjadi bagiannya. Reading pemain dengan script continuitylebih 
sering dilakukan dibandingkan reading pemain dengan sutradara karena, reading dengan sutradara akan diganti dengan direct langsung sutradara dengan pemain di lokasi pengambilan gambar (set). Strategi yang digunakan pada proses ini adalah mengirimkan skenario utuh ke pemain melalui email ataupun whatsapp. Pemain dapat membaca skenario sebelum proses produksi dilakukan. Hal tersebut dapat menjadi strategi untuk efisiensi waktu, tenaga, pikiran dan biaya.

\section{b. Set Lokasi}

Set lokasi adalah proses penataan lokasi produksi, untuk melakukan set lokasi maka dibutuhkan kerjasama antara astrada set, sutradara dan DOP. Set lokasi dilakukan setelah mendapat perintah dari astrada shcedule untuk scene berapa yang akan diambil gambarnya terlebih dahulu. Perbandingan antara penggunaan lokasi yang sama tetapi pada judul yang berbeda juga merupakan strategi Starvision untuk menekan biaya produksi, karena sering menggunakan lokasi yang sama, pihak Starvision sudah tidak lagi dipersulit dalam hal perizinan dan sudah paham akan bloking kamera, sehingga hal tersebut juga menjadi strategi untuk menghemat waktu produksi.

\section{c. Set Alat}

Set alat adalah penempatan alat di lokasi yang telah disetujui oleh sutradara dan DOP atas masukan dari astrada set. Penempatan alat akan dilakukan setelah DOP memberi perintah kepada juru kamera, divisi lighting dan properti. Lalu mereka akan mulai pekerjaan sesuai divisi masing masing. Strategi yang digunakan pada tahapan set alat adalah satu komando yang bertujuan untuk menghemat waktu dan tenaga. Berdasarkan observasi yang dilakukan oleh peneliti, penggunaan strategi satu komando dirasa sangat efektif karena jika didapati banyak komando, maka kru akan merasa bingung.

\section{d. Wardrobe dan Makeup}

Makeup adalah proses memberikan tatanan rambut, tatanan kostum, tata rias dari individu ke pemain. Wardrobe adalah segala sesuatu yang dipakai dan dibawa oleh pemain. Proses makeup dilakukan setelah tim makeup mendapat perintah scene berapa yang akan diambil gambar terlebih dahulu. Makeup dan kostum akan disesuaikan dengan tema yang telah dicantumkan di skenario dan yang telah disetujui oleh sutradara saat proses diskusi internal. Kostum yang dimiliki oleh Starvision jumlahnya masih terbatas. Untuk mensiasati hal tersebut maka pihak Starvision mencari vendor yang mau meminjamkan kostumnya untuk produksi FTV. Selain itu solusi lainnya adalah pemain menggunakan pakaiannya sendiri saat produksi. Untuk proses makeup di Starvision memiliki strategi guna efisiensi waktu dan tenaga dengan memberdayakan kru tata rias yang mampu menguasai segala macam makeup. Sehingga Starvision tidak perlu mendatangkan MUA yang secara otomatis akan menambah biaya produksi. Makeup juga dilakukan oleh masingmasing pemain saat melakukan touch up dengan dibantu oleh tim makeup. Menurut peneliti, jika pemain menggunakan kostum melalui vendor, maka hal tersebut dapat meringankan biaya produksi, karena biaya produksi akan lebih rendah untuk loundry dari pada membeli kostum baru.

Terkait dengan budaya Indonesia, pemilihan wardrobe disesuaikan dengan siapa yang memakai, dari mana ia berasal dan siapa dia. Pada judul FTV Starvision Backpaker Kece Tapi Kere, para pemain menggunakan kostum dan wardrobe budaya Jawa karena lokasi atau setting judul ini adalah Yogyakarta. Contoh, menggunakan kostum batik dan kebaya, 
dan saat pernikahan pun menggunakan adat Jawa.

\section{e. Proses Pengambilan Gambar}

Proses pengambilan gambar saat produksi FTV di Starvision dilakukan langsung oleh DOP dibantu oleh juru kamera. Juru kamera bisa menjadi asisten DOP. Strategi yang digunakan dalam tahapan pengambilan gambar adalah pengambilan gambar dilakukan langsung oleh DOP. Juru kamera akan mengambil gambar jika shot tersebut melalui beberapa re-take, maka tugas pengambilan gambar akan diberikan kepada juru kamera. Hal tersebut menjadi strategi untuk efisiensi waktu dan tenaga pada proses produksi. Menurut peneliti, penggunaan kamera Canon EOS 5D Mark III dapat mempermudah dan mempercepat proses produksi FTV di Starvision, karena praktis, dan tidak terlalu beresiko jika file hilang. Selain itu, penggunaan memory card sebagai penyimpanan akan mengurangi biaya produksi karena jika memory card penuh file dapat langsung di backup dan dapat digunakan kembali. Sedangkan jika memakai kaset untuk penyimpanannya, apabila kapasitas sudah penuh harus membeli yang baru.

\section{Pascaproduksi}

Pascaproduksi adalah tahapan dimana proses pengerjaannya setelah prapoduksi dan produksi terlaksana. Pada tahapan pascaproduksi, materimateri yang telah diambil saat proses produksi akan masuk ke tahap editing. Proses editing di Starvision melalui beberapa tahapan, yaitu berawal dari seorang drafter menyusun shot-shot yang telah diambil pada proses produksi secara kasar terlebih dahulu (tanpa diedit, langsung temple per file). Susunan dari drafter ini belum memperdulikan cerita dan rasa, setelah disusun oleh drafter barulah seorang editor turun tangan untuk menyusun shot-shot tersebut dengan lebih rapi sesuai cerita dan memberikan rasa didalamnya hingga membuahkan hasil FTV. Setelah hasil jadi, barulah proses review dengan sutradara beserta produser.

\section{Evaluasi}

Tahapan evaluasi yang dilakukan oleh Starvision ialah mengevaluasi keseluruhan FTV dengan cara ditarik mundur, dicari kesalahannya dimana, dari proses pascaproduksi, proses produksi, tahapan perencanaan, atau bahkan dalam pemilihan sinopsis. Mengevaluasi hasil produksi merupakan strategi yang digunakan Starvision agar dapat memproduksi FTV dengan lebih baik lagi. Kesalahan yang didapat dari tayangan FTV sebelumnya dijadikan sebagai acuan untuk produksi FTV judul selanjutnya.

\section{PENUTUP}

\section{Simpulan dan Saran}

Penelitian mengenai strategi manajemen produksi FTV di Starvision terhadap anggaran biaya produksi terkait budaya Indonesia menghasilkan beberapa kesimpulan. Kesimpulan dari makalah ini adalah bahwa Starvision menerapkan strategi manajemen produksi mulai dari tahap praproduksi, produksi, pascaproduksi hingga tahap evaluasi. Hal tersebut dilakukan dengan tujuan agar Starvision dapat melakukan efisiensi waktu, tenaga, dan anggaran biaya produksi. Strategi lain yakni menggunakan lokasi, dialog, logat, kostum, properti yang sangat kental dengan Budaya Indonesia. Seperti telah dijabarkan dalam bab sebelumnya, bahwa untuk memproduksi sebuah judul FTV atau satu episode tayangan FTV, Starvision harus menyelesaikannya dalam waktu lima hari. Durasi tayangan per episode atau per judul adalah 120 menit. Tentu saja hal tersebut tidaklah mudah untuk dilakukan, akan 
tetapi Starvision tetap dapat memproduksi FTV untuk ditayangkan di SCTV sejak tahun 2008 sampai saat ini dengan lancar. Produksi FTV ini yang utama adalah kuantitas, meskipun tetap menjaga kualitas tayangan. Dengan efektifnya waktu produksi, secara otomatis pengeluaran biaya produksi juga akan efisien. Hasil dari penelitian ini menyimpulkan bahwa Starvision dalam memproduksi FTV menggunakan beberapa strategi dalam setiap tahapan produksinya. Mulai dari tahapan praproduksi, produksi, pascaproduksi dan evaluasi. Strategi tersebut antara lain, menggunakan pemain dengan artis pendatang baru yang honornya masih rendah, penggunaan lokasi yang sering digunakan agar segi perizinan dipermudah, dan penggunaan vendor untuk peralatan dan kostum pemain untuk produksi, dan lainlain. Terkait dengan budaya Indonesia, budaya dan kebudayaan saling terkait dan bersinggungan. Demikian pula dalam tayangan FTV, mulai dari pencarian ide hingga proses edit FTV, budaya tersebut sangat dekat dengannya. Penentuan ide, penulisan skenario, penentuan judul, pemilihan lokasi dan pemain pun sangat terkait dengan budaya Indonesia. Bahasa dan logat pun menyesuaikan dengan budaya apa yang akan diangkat atau dijadikan ide dalam pembuatan FTV. Pemilihan lokasi untuk proses syuting, pemilihan pemain dengan logat dan bahasa yang sesuai dengan cerita, properti yang dibutuhkan, kostum yang digunakan, kesenian apa yang akan diangkat pada tayangan FTV Starvision, semua itu mencerminkan bahwa tayangan FTV Starvision sangat dekat dengan budaya Indonesia. Sehingga budaya Indonesia dapat dipopulerkan atau dipromosikan melalui tayangan FTV SCTV. Strategi-strategi tersebut digunakan dan bertujuan agar dapat mengenalkan budaya Indonesia melalui media televisi khususnya tayangan FTV.

\section{DAFTAR PUSTAKA}

\section{Sumber Buku :}

Andi Fachruddin. (2016). Manajemen Pertelevisian Modern. Yogyakarta: Andi Offset.

Anton Mabruri KN. (2013). Manajemen Produksi Program Acara Televisi Format Acara Drama. Jakarta: PT. Grasindo.

Burhan Bungin. (2012). Metodologi Penelitian Kualitatif.Jakarta: Raja Grafindo Persada

Cleve, Bastian. (2000). Film Production Management Second Edition. America: Focal Press.

Husaini Usman dan Purnomo Setiadi Akbar. (2009). Metodologi Penelitian Sosial. Jakarta: PT. Bumi Aksara.

Lexy. J. Moleong. (2000). Metodologi Penelitian Kualitatif. Bandung:PT Remaja Rosdakarya.

Morissan. (2008). Manajemen Media Penyiaran Strategi Mengelola Radio \& Televisi. Jakarta: Kharisma Putra Utama

Munandar. (1997). Budgeting: Perencanaan Kerja, Pengkoordinasian Kerja, dan Pengawasan Kerja. Edisi Pertama. Yogyakarta: BPFE UGM.

Sugiyono. (2006). Metode Penelitian Pendidikan: Pendekatan Kuantitatif dan Kualitatif dan $R \& D$. Bandung: Alfabeta. 
Suharsini Arikunto. (2002). Prosedur Penelitian Suatu Pendekatan Praktek. Jakarta: PT. Rineka Cipta.

Syd Field. (1994). The Foundations of Screen Writing. United States: Dell Publishing Company.

Tino Saroenggalo. (2008). Dongeng Sebuah Produksi Film. Jakarta: PT. Intisari Mediatama.

\section{Sumber lain :}

Academia. (2018). Ming Muslimin: Manajemen Produksi Film (Pengantar). Academia. (http://www.academia.edudiakses pada 22 Februari 2018, pukul 16.00 WIB)

Academia. (2018). Jasa Point: Teori Pengelolaan.

Academia. (http://www.academia.edudiakses pada 1 Maret 2018, pukul 13.00 WIB)

Blogspot Ridwan Rayhan. 17 Juli 2013. Ridwan Rayhan: Tahap Pra Produksi

.(http://ridwanrayhan.blogspot.co.id/ diakses pada 1 Maret 2018, pukul 15.00 WIB)

CSinema. (2014). Tahapan Produksi Film: Produksi. Diakses pada 26 Februaru 2018.

CSinema. (2014). Tahapan Produksi Film: Development. CSinema: (http://csinema.com/tahapanproduksi-film-produksi/diakses pada 26 Februari 2018)

CSinema. (2014). Tahapan Produksi Film: PraProduksi. CSinema: (http://csinema.com/tahapanproduksi-film-praproduksi/diakses pada 26 Februari 2018)
Ensiklopedia. (2018). Film Televisi. Film Televisi Ensiklopedia: (http://modem.igi.web.iddiakses pada 14 Januari 2018)

Scribd. (2018). Manajemen Produksi Film $T V$. (https://www.scribd.comdiakses pada 22 Februari 2018)

SCTV FTV. (2015). SCTV FTV-SCTV Show.SCTV:

(http://www.sctv.co.iddiakses pada 26 Februari 2018)

Thegorbalsla. (2019). Pengertian Kebudayaan : Unsur Unsur, Fungsi, Wujud, dan Contoh. Thegorbalsla: (http://thegorbalsla.com/pengertiankebudayaan/diakses 24 November 2019) 